\title{
Implications of the COVID-19 pandemic on funding basic
} education

Thiago Alves 1

Nalú Farenzena ${ }^{2}$

Adriana A. Dragone Silveira ${ }^{3}$

José Marcelino de Rezende Pinto ${ }^{4}$

1 Universidade Federal de Goiás / School of Business, Accounting and Economic Sciences/ Graduate Program in Business Administration, Goiânia / GO - Brazil

2 Universidade Federal do Rio Grande do Sul / Faculty of Education, Graduate Program in Education, Porto Alegre / RS - Brazil

${ }^{3}$ Universidade Federal do Paraná / School Planning and Management Department, Graduate Program in Education, Curitiba / PR - Brazil

${ }^{4}$ Universidade de São Paulo / Faculty of Philosophy, Sciences and Languages of Ribeirão Preto, Graduate Program in Education,

Ribeirão Preto / São Paulo - Brazil

This article aims to estimate the impact of lower tax revenues on the funding of basic education, in the context of the economic impact of the COVID-19 pandemic. Three hypothetical scenarios of lowering tax revenues are estimated and analyzed, along with their effects on the investment in education in the states and municipalities, per-pupil and overall, using a methodology that combines data on tax revenues, mandatory allocation in education, and enrollment numbers. In the most optimistic scenario, the reduction of $7 \%$ in the net tax revenues would lead to a decrease in investment in basic education of more than $\mathrm{R} \$ 16.6$ billion. The monthly per-pupil expenditure, which in 2018 was R 460 on average, could drop between $4.1 \%$ and $26.9 \%$ depending on which scenario is considered. This probable reduction in revenues requires urgent measures to attenuate the deepening of educational inequalities, converging to the transference of federal funds to sub-national governments. Finally, we highlight the economic virtue of investing in education, when considering the capillarity of education, and its character of intensive investment in personnel.

Keywords: COVID-19; school funding; educational inequalities; educational policies.

\section{Implicações da pandemia da COVID-19 para o financiamento da educação básica}

O objetivo do presente artigo é estimar impactos da queda da arrecadação tributária para o financiamento da educação básica em virtude dos efeitos econômicos adversos da pandemia da COVID-19. Para tanto, são analisados três cenários hipotéticos de queda da arrecadação e seus efeitos para as receitas da educação nos estados e municípios, por meio de um modelo de previsão que combinou dados de receitas de impostos com receitas vinculadas a educação e matrículas. No cenário mais otimista, a redução da receita líquida de impostos de $7 \%$ implicaria um decréscimo dos recursos para educação básica de R \$ 16,6 bilhões por ano. A receita aluno-mês, que, em 2018, foi de R \$ 460, em média, poderia cair em proporções que variam entre $4,1 \%$ e $26,9 \%$, a depender do cenário de redução e do contexto de cada município. Diante da previsível diminuição de recursos, são propostas medidas urgentes para atenuar o aprofundamento das desigualdades na educação, as quais convergem para a transferência de recursos da União aos governos subnacionais. Finalmente ressalta-se o papel virtuoso do investimento na educação, dada a capilaridade desta e o seu caráter intensivo em pessoal.

Palavras-chave: COVID-19; financiamento da educação básica; desigualdades educacionais; políticas educacionais. 


\title{
Implicaciones de la pandemia de COVID-19 para la financiación de la educación básica
}

\begin{abstract}
El objetivo del artículo es estimar los impactos de la caída de la recaudación tributaria en el financiamiento de la educación básica frente a los efectos económicos adversos de la pandemia de COVID-19. Para ello, se analizan tres escenarios hipotéticos de caída de la recaudación y sus efectos sobre el presupuesto educativo y por alumno en los estados y municipios, por medio de una metodología que combinó datos de ingresos tributarios, recursos impositivos vinculados a la educación y matrículas. En el escenario más optimista, la reducción del 7\% de los ingresos tributarios líquidos implicaría una disminución de los recursos para la educación básica de $\mathrm{R}$ \$16,6 mil millones. Los recursos mensuales por alumno que en 2018 fueron de R \$460, en promedio, podrían caer de 4,1\% a 26,9\%, dependiendo del escenario de reducción. Frente a la previsible disminución de recursos, se proponen medidas urgentes para atenuar la profundización de las desigualdades en la educación, las cuales convergen en la transferencia de recursos federales a los gobiernos subnacionales. Finalmente se resalta el papel virtuoso de la inversión educativa en la economía, dada la capilaridad de la educación y su carácter intensivo en personal.
\end{abstract}

Palabras clave: COVID-19; financiamiento de la educación básica; desigualdades educativas; políticas educativas.

\section{INTRODUCTION}

The confirmation of the first case of contamination by the new coronavirus (COVID-19) in Brazil in the last days of February has placed authorities on alert and, gradually, rules for social distancing were imposed in order to mitigate the increase in the number of cases. From the second half of March onwards, in several Brazilian states, educational institutions stopped live activities because of regulations which have imposed restrictions on their operation. Furthermore, due to the lack of governability of municipalities and states, third-party companies began to dismiss temporary teachers, trainees, cleaning and food workers.

In this context, the negative impacts of the crisis on students from public schools, who depend primarily on schools to exercise their right to education, are highlighted. In contrast to private schools, most students in the public school district do not have appropriate conditions (computers, internet access, physical space, furniture, etc.) for conducting educational activities at home. Moreover, the nutritional impact on a significant number of extremely poor children is enormous, since, together with the lessons, they have also lost access to school meals.

Despite the immediate and fundamental challenges to pedagogical process arising from the pandemic, this article addresses the impacts of the declining tax revenue on the financing of public basic education schools. The underpinning assumption is that reducing resources for the education sector can considerably worsen inequalities in the conditions of education supply, especially in the poorest regions and localities with lower tax revenues.

One of the short-term consequences of the pandemic is the considerable reduction in economic activities, which has negative repercussions on tax collection. World Bank studies (World Bank, 2020) estimate 5\% drop in Brazil's Gross Domestic Product (GDP) in 2020, and others, a 20\% to 30\% drop in the tax collection on the Circulation of Merchandise and Services and the Rendering of Interstate and Intermunicipal Transportation Services and Communications (ICMS - Imposto sobre Circulação de Mercadorias e Serviços) in April compared to March (Watanabe, 2020). Therefore, taking into account that the main source of funding for public schools of basic education is the binding of tax revenues (RLI - Receitas Líquidas de Impostos), it is foreseeable that there will be an intense loss of 
resources for education, as studies already indicate in countries whose educational funding system are similar to Brazil (Baker \& Di Carlo, 2020).

Brazilian public education relies on earmarked revenues, which guarantee it a certain stability. Nevertheless, they are insufficient to provide a good standard of educational quality and to reduce inequalities in the conditions of education offer. These differences are caused by the disparity in the capacity of expenditure per student between states and municipalities, as evidenced by studies on achieving the goals of National Education Plan 2014-24 (Plano Nacional de Educação, PNE, Law 13005) (National Institute of Research on Education [INEP - Instituto Nacional de Estudos e Pesquisas Educacionais Anísio Teixeira], 2018). The average expenditure per student in Brazil is about one-third of the average in Organization for Economic Cooperation and Development (OECD, 2019) countries and less than one-half of that in Brazilian private schools attended by middle-class students.

This article presents a brief picture of educational offer and financing in Brazil, and forecasts scenarios of tax collection in this context of economic recession and their effects on educational revenue in states and municipalities. The final considerations highlight urgent measures to mitigate the deepening of educational inequalities.

\section{CHALLENGES OF BRAZILIAN EDUCATIONAL FEDERALISM}

State actions in basic education are carried out through a complex structure of intergovernmental relations and institutions which have managerial and regulatory functions. They are conducted on the basis of the collaborative system between the Union, states and municipalities, as established in the Federal Constitution (Constituição Federal - CF, art. 211, 1988). According to the School Census-2018, the public system offered 39.5 million enrollments ( $81.4 \%$ of the total basic education enrollments) in 141,300 schools with 1.86 million teachers. This offer is distributed in almost 6,000 subnational districts of public schools (26 under states governments, 01 under Federal District government and 5,570 under municipalities governments). In 2018, the state districts represented $33 \%$ of the enrollments; the municipal ones, $48 \%$; and the private schools, $19 \%$. In view of such a large public school district and the inexistence of a National Education System, it is reasonable to expect that the State will have great challenges in terms of federal coordination and cooperation to address the educational consequences of the pandemic.

Another outstanding challenge to the public education system's performance, besides its coverage extension, is the historical social inequality of Brazil. According to Cury (2008), such disparity is expressed in the victimization of migrants, peripheries and rural areas residents, poor, blacks, indigenous, and old people. Table 1 shows how the stratification of educational opportunities associated with the level of population income, a recurring phenomenon in developing countries (Alves \& Silva, 2013; Barros, Mendonça, Santos, \& Quintaes, 2001; Buchmann \& Hannum, 2001), is configured from the perspective of access and school process completion.

The data in Table 1 emphasize the important role of public schools in ensuring the right to education for the poorest population. They also demonstrate, considering the income level, the difference in access to early childhood education, a stage that has a significant impact on the children's school career (Bakken, Brown, \& Downing, 2017; Phillips et al., 2017). This, to some degree, is reflected in the gap between the richest $10 \%$ and the poorest $50 \%$ in the illiteracy rate (difference of 23 times) and in the completion of high school (2.4 times) and higher education (17 times). 


\begin{tabular}{|c|c|c|}
\hline Characteristics & Poorest $50 \%{ }^{1}$ & Richest $10 \%{ }^{2}$ \\
\hline Educational attainment rate 0 - 3 years & $29.0 \%{ }^{*}$ & $53.2 \%$ \\
\hline Educational attainment rate 4 - 5 years & $90.8 \%{ }^{*}$ & $98.3 \%$ \\
\hline Educational attainment rate $6-14$ years & $99.2 \%^{*}$ & $99.9 \%$ \\
\hline Educational attainment rate 15 - 17 years & $89.3 \%{ }^{*}$ & $99.4 \%$ \\
\hline Population 4-17 years attending public school ${ }^{3}$ & $94.8 \%{ }^{*}$ & $10.4 \%$ \\
\hline Illiteracy rate 15 years and over & $9.3 \%{ }^{*}$ & $0.4 \%$ \\
\hline Population 25 to 65 years who have completed high school & $34.8 \%{ }^{*}$ & $90.5 \%$ \\
\hline Population 25 to 65 who have completed undergraduate education & $4.2 \%{ }^{*}$ & $64.1 \%$ \\
\hline
\end{tabular}

\section{Notes:}

(1) In 2018, the poorest 50\% had household family income per capita of up to $\mathrm{R} \$ 788$ (0.83 minimum wage).

(2) In 2018, the richest $10 \%$ had household family income per capita of $\mathrm{R} \$ 2,600$ (2.7 minimum wages) or more.

(3) Values related to the population of municipalities in the capitals of Brazilian states.

$\left({ }^{*}\right)$ Chi-square test results showed significant differences between income levels $(p<0.001)$.

Source: Elaborated by the authors based on data from Continuous National Household Sample Survey (PNAD - Pesquisa Nacional por Amostra de Domicilios Contínua) of 2nd quarter/2018.

Regarding the responsibilities of federative entities, national regulations assign municipalities priority in elementary and early childhood education, whereas states give priority in elementary and high schools. The Union must organize and support the federal public institutions and provide financial and technical assistance to subnational governments to balance opportunities and ensure a minimum standard of education quality (CF [Art. 211], 1988).

In terms of financing, the Federal Constitution (CF, 1988) establishes application of a minimum percentage of the government's income net of tax for maintaining and developing education - $18 \%$ for the federal government and $25 \%$ for subnational entities. This is the main source for education, followed by education-salary, social contribution levied by companies, and calculated upon the total remuneration of insured employees. The funding is directed to the financing of public basic education, with portions divided among the federation entities.

As regards sharing expense, in 2015, of a total of $\mathrm{R} \$ 321.3$ billion in public spending on fiscal resources, the municipalities were responsible for 38.2\%, then the States and the Federal District, with $32.5 \%$, and the Union, with only $29.3 \%$ (Inep, 2018). The greatest effort is made by subnational governments, with direct action in providing basic education and relatively less appropriation of all taxes collected.

The federative collaboration in financing is achieved through policies of intergovernmental transfers of resources, being the main one the Fund for Maintenance and Development of Basic Education and Valuation of Education Professionals (Fundeb - Fundo de Manutenção e Desenvolvimento da Educação Básica e de Valorização dos Profissionais da Educação), in operation since 2007, which will end in 2020. Fundeb has made possible a greater equality in the spending capacity of the federation entities but given the small value of the federal complement, great differences persist, and value per student is very low (Pinto, 2018). 


\section{METHODOLOGICAL ISSUES}

The analysis of the impact of the drop in revenue, resulting from the economic effects of the health crisis on states and municipalities basic education budget, was conducted by using a model that made it possible to build scenarios for predicting the tax revenues mandatorily allocated in education. The following four elements based this model:

(1) database comprising characteristics of educational offer; sources of revenues of states and municipalities; distribution coefficients of Fundeb resources; values of the complementation of the Union to Fundeb;

(2) percentage decrease in the collection of ICMS and Municipal Service Tax (ISS - Imposto sobre Serviços) and revenues from the State Participation Fund (FPE - Fundo de Participação dos Estados), Municipality Participation Fund (FPM - Fundo de Participação dos Municípios), ICMS Exemption and ICMS share;

(3) computation of the 'minimum potential earmarked revenue for basic education'1 (RPEb - receita potencial mínima vinculada para educação básica) for each state and municipality based on the following formula:

$$
R P E b=(25 \% x R L I)-(R D F)+(R R F)+(C O U N)
$$

Where:

${ }^{\star} R P E b=$ Minimum potential earmarked revenue for basic education

${ }^{\star} R L I \quad=$ Binding of tax revenues ${ }^{1}$

${ }^{\star} R D F=$ Revenue for the state Fundeb ${ }^{2}$

${ }^{\star} R R F=$ Revenue obtained from the state Fundeb ${ }^{3}$

${ }^{\star}$ COUN $=$ Complementation of the Union to Fundeb ${ }^{4}$

\section{Notes:}

(1) State tax revenue - ICMS (deducted of 25\% to compose the ICMS share), - Tax on Property Transmission Causa Mortis (ITCD - Imposto sobre Transmissão Causa mortis e Doação), Tax on Automotive Vehicles (IPVA - Imposto sobre Propriedade de Veículos Automotores) (deducted of 50\% to compose the IPVA share); municipal Tax - ISS, Urban Building and Land Tax (IPTU - Imposto Territorial, Predial e Urbano), municipal Tax on Transfer of Real Estate (ITBI - Imposto sobre a Transmissão de Bens Imóveis), Rural Land Tax (ITR - Imposto Territorial Rural); revenues from transfers to states (FPE share); revenues from transfers to municipalities (FPM share, ICMS share, IPVA share, ITR share) and transfers to states and municipalities - ICMS Tax exemption, Tax on Financial Operations (IOF - Imposto sobre Operações Financeiras), Gold and Industrialized Product Tax share (IPI - Imposto sobre Produto Industrializado) Export tax (deducted of 25\%); in addition to the Withholding Income Tax (IRRF - Imposto sobre a Renda Retido na Fonte) by state and municipal agencies.

(2) In each state Fundeb is composed by $20 \%$ of the net revenue of ICMS, IPVA, ITCD, FPE share, ICMS share, IPVA share, FPM share (point b), ITR share, ICMS exemption, IPI share Export.

(3) The total revenue of each state fund is internally redistributed among the federative entities of the respective states based on the number of enrollments in the previous year with weightings (Art 9, Law 11494/2007).

(4) The Union must complement with at least $10 \%$ of the total resources directed by states and municipalities the funds with lower value per student per federated unit.

Source: Elaborated by the authors.

\footnotetext{
${ }^{1}$ The expression "minimum potential revenue" is derived from the provisions of Art. 212 of the CF(1988), which establishes a minimum percentage of the revenue resulting from taxes and transfers. Therefore, the proposed indicator is a conservative measure, since federal entities may use a value beyond the minimum.
} 
(4) Computation of the 'monthly income per student' indicator to enable comparison of results between federal entities, based on the following formula:

$$
\text { Monthly_income_per_student }=(R P E b) /\left(n \_e n r r\right) / 12
$$

Where:

${ }^{\star} R P E b=$ Minimum potential earmarked revenue for basic education (annual amount)

${ }^{\star} n \_$enrr $=\quad$ Number of enrollments in the own public district (state or municipal) + offers in accredited private institutions

Source: Elaborated by the authors.

The study database was created with data from 2018 (base year for comparison of revenues). The federative entity (states and municipalities) was the analysis unit. The base was composed of 5,596 observations (26 states, Federal District and 5,570 municipalities). No revenue data were obtained from 38 municipalities. Thus, we reached a coverage of 5,558 or $99.3 \%$ of the federative entities responsible for suppling of $99.7 \%$ of the enrollment in the state and municipal public districts - see variables and data sources in Box 1.

\section{BOX 1 VARIABLES AND DATA SOURCES}

\begin{tabular}{lll} 
Aspect & \multicolumn{1}{c}{ Variables } & \multicolumn{1}{c}{ Source } \\
\cline { 2 - 3 } Public revenue & $\begin{array}{l}\text { ICMS, ITCD, IPVA, FPE Share, IPTU, ITBI, ISS, IRRF, FPM, ICMS } \\
\text { Share, ICMS Exemption, IPI Share, Export, IPVA Share, ITR, ITR } \\
\text { share, IOF Gold Share }\end{array}$ & $\begin{array}{l}\text { Analytical Data Siope/FNDE; RREO/ } \\
\text { Siconfi/STN; Constitutional Transfers } \\
\text { platform /STN (2018) }\end{array}$ \\
Education funding & $\begin{array}{l}\text { Coef_distribution_resources_Fundeb, } \\
\text { Coef_distribution_complementation_Union }\end{array}$ & \\
\cline { 2 - 3 } Context & Number of enrolments & School Census Microdata /Inep (2018)
\end{tabular}

Source: Elaborated by the authors.

Concerning the second element, the aim was to build a model for analyzing the impact of the drop in education funding and not to make highly accurate forecasts. Hence, three scenarios were considered. In the first situation, the most optimistic one, annual reduction in ICMS tax collection, ICMS share, ICMS exemption and ISS of $10 \%$, and drop of $5 \%$ in the FPE and $\mathrm{FPM}^{2}$ transfers. In

\footnotetext{
${ }^{2}$ Provisional Measure 938/2020 established financial support to states and municipalities via the FPE and FPM. That happened to maintain the level of resources for the same period of 2019, from March to June. Considering the short period established for this assistance, as well as the limit of its values, reductions were applied to both funds (MP, 2020).
} 
Scenario II, annual drop of $20 \%$ and $10 \%$ in the two revenue groups considered, respectively. In Scenario III, the pessimistic view, $30 \%$ and $15 \%$ drop, respectively.

The third and fourth elements of the model consists in the calculation of indicators of results. In these stages RPEb and 'monthly income per student' for each state and municipality were calculated. They composed the sample of 5,558 federal entities analyzed, considering the percentage of reducing revenue in the sources specified in each scenario. To estimate the drop in revenue, the results of each federal entity, in the three scenarios, were compared to the amount carried out in the base year (2018). The calculations, as they were numerous (three scenarios x 5,558 federal entities), were made using a computer program developed in a statistical software.

The results reported in the next section were generated based on the aggregation (summation) of the results of each federative entity, for different levels of analysis: Table 2 presents the impact of each scenario on the national aggregate; and Table 3 presents aggregated results by state. In a different perspective of analysis, Table 4 focuses on the variation of 'monthly income per student' in each scenario.

\section{SCENARIOS OF REDUCED TAX COLLECTION AND CONSEQUENCES FOR BASIC EDUCATION}

Table 2 provides data on income collection and earmarked revenues for basic education in 2018. Of the RLI of R $\$ 900.3$ billion in 2018, 52.4\% is composed of ICMS (including the share transferred to the municipalities and the ICMS exemption). FPE and FPM account for $21.2 \%$ and ISS for $7.2 \%$. The other sources compose less than one fifth of the revenue. The resources for financing education ( $\mathrm{R} \$ 238.9$ billion) originated from the binding of $25 \%$ of these revenues from states and municipalities ( $\mathrm{R} \$ 225.1$ billion [ $94.2 \%$ of the total]) and the complementation of the Union to Fundeb $(\mathrm{R} \$ 13.8 \text { billion [5.8\% of the total]) })^{3}$. The state schools, as a whole, received $56.4 \%$ of the resources ( $\mathrm{R} \$ 134.8$ billion) and the municipal schools $43.6 \%$ ( $\$ 104.1$ billion). In the national aggregate, these sources of financing ensured a monthly income per student of $\mathrm{R} \$ 492.00$ for 40.5 million enrollments.

In the first scenario, there was a 7\% drop in earmarked revenues for basic education, a loss of $\mathrm{R} \$ 16.6$ billion, of which $\mathrm{R} \$ 10.3$ billion among state and $\mathrm{R} \$ 6.3$ billion among municipal schools. The income per student would drop to $\mathrm{R} \$ 458.00$ per month. The second scenario resulted in a $14 \%$ decrease in the RLI, a loss of R 33.5 billion in education budgets and a drop in monthly income per student to $\mathrm{R} \$ 423.00$. Finally, in the worst scenario, there would be a $21.1 \%$ drop in the RLI, which would negatively impact education resources by $\mathrm{R} \$ 50.4$ billion, resulting in a monthly income per student of only $\mathrm{R} \$ 388.00$.

The data in Table 3 show an overview of the diversity of educational offer by Federation Unit (UF - Unidade da Federação) in number of public schools and enrollment. It also emphasizes the inequality of the financing capacity expressed by the median of monthly income per student. In this respect, the distance between the lowest ( $\mathrm{R} \$ 323.00$ relative to Maranhão) and the highest value ( $\mathrm{R} \$ 610.00$ relative to Rio Grande do Sul) is $90 \%$. The numbers indicate a significant intra- and interregional disparity. A disaggregated analysis by federative entity shows that the monthly income per student of $\mathrm{R} \$ 460.00$ (average of 2018) may drop from $4.1 \%$ to $26.9 \%$, depending on the scenario of reduction and context of each municipality.

${ }^{3}$ Given the scope of this study and the lack of data per federated entity, the educational salary was not included. In spite of that, its gross revenue was $\mathrm{R} \$ 22.1$ billion in 2018 . 


\section{TABLE 2 EARMARKED REVENUE FOR BASIC EDUCATION FINANCING AND REDUCTION OF TAX COLLECTION SCENARIOS - BRAZIL/2018 (IN BILLION R\$)}

\begin{tabular}{|c|c|c|c|c|c|}
\hline \multirow[t]{2}{*}{ Revenue source } & \multicolumn{2}{|l|}{$\begin{array}{c}\text { Annual revenue } \\
\text { of } 2018\end{array}$} & \multirow{2}{*}{$\begin{array}{c}\text { Scenario I } \\
\text { R\$ }\end{array}$} & \multirow{2}{*}{$\begin{array}{c}\text { Scenario II } \\
\text { R\$ }\end{array}$} & \multirow{2}{*}{$\begin{array}{c}\text { Scenario III } \\
\text { R\$ }\end{array}$} \\
\hline & $\mathrm{R} \$$ & $\%$ & & & \\
\hline ICMS & 355.7 & 39.5 & 320.1 & 284.5 & 249.0 \\
\hline ICMS share & 114.0 & 12.7 & 102.6 & 91.2 & 79.8 \\
\hline FPM & 101.3 & 11.3 & 96.3 & 91.2 & 86.1 \\
\hline FPE & 89.4 & 9.9 & 85.0 & 80.5 & 76.0 \\
\hline ISS & 65.1 & 7.2 & 58.6 & 52.1 & 45.6 \\
\hline ICMS exemption & 1.9 & 0.2 & 1.7 & 1.5 & 1.3 \\
\hline Other sources & 172.9 & 19.2 & 172.9 & 172.9 & 172.9 \\
\hline Binding of tax revenues (RLI) & 900.3 & 100.0 & 837.1 & 773.9 & 710.7 \\
\hline Estimated reduction in $\mathrm{RCL}$ & & & $-7.0 \%$ & $-14.0 \%$ & $-21.1 \%$ \\
\hline Basic Education Funding & & & & & \\
\hline $25 \%$ of the Current Net Revenue & 225.1 & 94.2 & 209.3 & 193.5 & 177.7 \\
\hline Complementation of the Union to Fundeb & 13.8 & 5.8 & 13.0 & 11.9 & 10.8 \\
\hline Minimum potential earmarked revenue (RPEb) & 238.9 & 100.0 & 222.3 & 205.4 & 188.5 \\
\hline Reduction of resources for education & & & -16.6 & -33.5 & -50.4 \\
\hline State school resources & 134.8 & 56.4 & 124.5 & 114.1 & 103.7 \\
\hline Estimated reduction: & & & -10.3 & -20.7 & -31.1 \\
\hline Resources for municipal schools & 104.1 & 43.6 & 97.83 & 91.32 & 84.80 \\
\hline Estimated reduction: & & & -6.3 & -12.8 & -19.3 \\
\hline Number of enrollments & $40,472,466$ & & $40,472,466$ & $40,472,466$ & $40,472,466$ \\
\hline Monthly income per student (in $\mathrm{R} \$ 1.00$ ) & 492 & & 458 & 423 & 388 \\
\hline
\end{tabular}

Source: Elaborated by the authors based on data from the Integrated Information System for Planning and Budget (Siope - Sistema de Informações sobre Orçamentos Públicos em Educação)/ National Education Development Fund (FNDE - Fundo Nacional de Desenvolvimento da Educação), of the Summary Budget Execution Report ( RREO - Relatório Resumido da Execução Orçamentária)/ Tax Information System of the Brazilian Public Sector (Siconfi - Sistema de Informações Contábeis e Fiscais do Setor Público Brasileiro)/ Secretariat of the National Treasury (STN - Secretaria do Tesouro Nacional), data from the portal 'Constitutional Transfers'/STN and in microdata from the School Census/Inep (2018). 


\section{TABLE 3 EARMARKED REVENUES AND RESOURCE REDUCTION ESTIMATE FOR FINANCING BASIC EDUCATION BY REGION AND UF-BRAZIL/2018}

\begin{tabular}{|c|c|c|c|c|c|c|c|c|}
\hline \multirow{3}{*}{ Region } & \multirow{3}{*}{ UF } & \multirow{3}{*}{$\begin{array}{c}\text { Number of } \\
\text { public school } \\
\text { districts1 }\end{array}$} & \multirow{3}{*}{$\begin{array}{c}\begin{array}{c}\text { Number } \\
\text { of }\end{array} \\
\text { enrollments2 }\end{array}$} & \multicolumn{2}{|c|}{ Revenues for 2018} & \multicolumn{3}{|c|}{ Estimated losses } \\
\hline & & & & $\begin{array}{l}\text { Earmarked } \\
\text { revenues3 }\end{array}$ & $\begin{array}{l}\text { Monthly } \\
\text { income per } \\
\text { student4 }\end{array}$ & Scenario I & Scenario II & Scenario III \\
\hline & & & & R\$ (bilhões) & $\mathrm{R} \$(1,00)$ & R\$ (bilhões) & R\$ (bilhões) & R\$ (bilhões) \\
\hline \multirow[t]{8}{*}{ North } & $\mathrm{AC}$ & 23 & 268,949 & 1.41 & 360 & 0.08 & 0.17 & 0.25 \\
\hline & AM & 63 & $1,071,569$ & 5.15 & 341 & 0.37 & 0.77 & 1.17 \\
\hline & $\mathrm{AP}$ & 17 & 204,973 & 1.22 & 402 & 0.07 & 0.13 & 0.20 \\
\hline & PA & 138 & $2,043,932$ & 9.18 & 329 & 0.59 & 1.26 & 1.94 \\
\hline & RO & 53 & 393,463 & 2.11 & 415 & 0.14 & 0.29 & 0.43 \\
\hline & $\mathrm{RR}$ & 16 & 141,056 & 0.94 & 456 & 0.06 & 0.11 & 0.17 \\
\hline & TO & 139 & 356,894 & 2.37 & 472 & 0.14 & 0.29 & 0.43 \\
\hline & Region & 449 & $4,480,836$ & 22.39 & 382 & 1.45 & 3.02 & 4.58 \\
\hline \multirow[t]{10}{*}{ Northeast } & $A L$ & 97 & 689,273 & 3.36 & 343 & 0.21 & 0.44 & 0.66 \\
\hline & $\mathrm{BA}$ & 417 & $3,054,741$ & 15.02 & 353 & 1.00 & 2.07 & 3.15 \\
\hline & CE & 185 & $1,786,525$ & 8.57 & 341 & 0.56 & 1.15 & 1.74 \\
\hline & MA & 214 & $1,831,674$ & 8.00 & 323 & 0.49 & 1.05 & 1.61 \\
\hline & PB & 224 & 806,985 & 3.86 & 351 & 0.25 & 0.51 & 0.77 \\
\hline & $P E$ & 185 & $1,730,761$ & 8.87 & 351 & 0.61 & 1.23 & 1.86 \\
\hline & PI & 222 & 857,513 & 3.84 & 358 & 0.24 & 0.50 & 0.76 \\
\hline & RN & 166 & 646,302 & 3.43 & 378 & 0.23 & 0.47 & 0.70 \\
\hline & SE & 76 & 421,827 & 2.54 & 415 & 0.16 & 0.32 & 0.49 \\
\hline & Region & 1,786 & $11,825,601$ & 57.51 & 351 & 3.76 & 7.75 & 11.75 \\
\hline \multirow[t]{5}{*}{ Southeast } & ES & 78 & 766,169 & 4.30 & 399 & 0.33 & 0.65 & 0.98 \\
\hline & $M G$ & 851 & $4,025,033$ & 21.78 & 430 & 1.52 & 3.04 & 4.56 \\
\hline & RJ & 92 & $2,472,561$ & 16.76 & 432 & 1.21 & 2.42 & 3.63 \\
\hline & $\mathrm{SP}$ & 643 & $8,137,989$ & 60.49 & 532 & 4.36 & 8.71 & 13.07 \\
\hline & Region & 1,664 & $15,401,752$ & 103.33 & 464 & 7.41 & 14.82 & 22.23 \\
\hline \multirow[t]{4}{*}{ South } & PR & 397 & $2,224,909$ & 13.75 & 478 & 0.95 & 1.89 & 2.84 \\
\hline & RS & 498 & $1,981,857$ & 13.57 & 610 & 1.03 & 2.06 & 3.09 \\
\hline & $\mathrm{SC}$ & 296 & $1,341,655$ & 8.86 & 531 & 0.65 & 1.30 & 1.94 \\
\hline & Region & 1,191 & $5,548,421$ & 36.18 & 541 & 2.62 & 5.25 & 7.87 \\
\hline
\end{tabular}




\begin{tabular}{|c|c|c|c|c|c|c|c|c|}
\hline \multirow{3}{*}{ Region } & \multirow{3}{*}{ UF } & \multirow{3}{*}{$\begin{array}{c}\text { Number of } \\
\text { public school } \\
\text { districts1 }\end{array}$} & \multirow{3}{*}{$\begin{array}{c}\text { Number } \\
\text { of } \\
\text { enrollments2 }\end{array}$} & \multicolumn{2}{|c|}{ Revenues for 2018} & \multicolumn{3}{|c|}{ Estimated losses } \\
\hline & & & & $\begin{array}{l}\text { Earmarked } \\
\text { revenues3 }\end{array}$ & $\begin{array}{c}\text { Monthly } \\
\text { income per } \\
\text { student4 }\end{array}$ & Scenario I & Scenario II & Scenario III \\
\hline & & & & R\$ (bilhões) & $\mathrm{R} \$(1,00)$ & R\$ (bilhões) & R\$ (bilhões) & R\$ (bilhões) \\
\hline \multirow{5}{*}{$\begin{array}{l}\text { Centre- } \\
\text { West }\end{array}$} & DF & 1 & 476,115 & 3.37 & 589 & 0.20 & 0.40 & 0.60 \\
\hline & GO & 246 & $1,234,143$ & 7.22 & 482 & 0.50 & 1.00 & 1.50 \\
\hline & MS & 80 & 613,167 & 3.83 & 481 & 0.27 & 0.53 & 0.80 \\
\hline & MT & 141 & 784,306 & 4.67 & 491 & 0.33 & 0.66 & 0.99 \\
\hline & Region & 468 & $3,107,731$ & 19.09 & 484 & 1.30 & 2.60 & 3.90 \\
\hline BRAZIL & & 5,558 & $40,364,341$ & 238.50 & 435 & 16.54 & 33.43 & 50.33 \\
\hline
\end{tabular}

\section{Notes:}

(1) Federated entities of the study sample. In each UF there is a state and municipal education districts.

(2) Number of enrollments of the municipal, state and affiliated institutions.

(3) $\operatorname{RPEd}=(25 \% \mathrm{x}$ RLI of each UF $)+($ Complementation of the Union to Fundeb, if there is any).

(4) Median of monthly income per student in each UF.

Source: Elaborated by the authors based on data from Siope /FNDE, RREO/Siconfi/STN data from the portal 'Constitutional Transfers'/ STN and in microdata from the School Census/Inep (2018).

Table 3 details, by state and region, the amounts needed to recompose the basic education budgets if tax reduction scenarios are confirmed. In scenario I, for instance, which would require $\mathrm{R} \$ 16.5$ billion nationally, $\mathrm{R} \$ 1.45$ billion should be allocated to the Northern states $(8.8 \%)$, $\mathrm{R} \$ 3.76$ billion to the Northeast (22.7\%), $\mathrm{R} \$ 7.41$ billion to the Southeast (44.8\%), $\mathrm{R} \$ 2.62$ billion to the Southern states (15.9\%), and R 1.3 billion to the Center-West (7.9\%). Some studies (Alves \& Silva, 2013; Inep, 2018) evidence that the states in the North and Northeast, in general, face greater educational challenges because of their access, offer conditions and results. The focus here, nevertheless, is the recomposition of budget amounts in the context of the COVID-19 pandemic, since each public school district in the country has historically made budgetary commitments to maintain its schools.

These numbers reveal one of the main limitations of the current basic education financing system: the public schools' financing capacity, which is associated with the collection capacity, in view of the local wealth. Thus, the system does not have an important characteristic: wealth or fiscal neutrality (Berne \& Stiefel, 1984). Thus, the conditions for ensuring the right to education are susceptible to the fiscal capacity of the locality where children, young people and adults live.

Table 4 illustrates that in 2018, the system for financing basic education produced, on average, a monthly income per student of $\mathrm{R} \$ 460.00$ for the 5,558 public schools districts analyzed, though with a significant inequality $(\mathrm{CV}=29.6 \%)$. 

SCHOOLS DISTRICTS ${ }^{1}$ AND THE REDUCTION OF SCENARIOS - BRAZIL/2018

\begin{tabular}{|c|c|c|c|c|c|c|c|c|}
\hline & & & Scen & & Scena & & Scena & io III \\
\hline Descriptive & easures & $\begin{array}{c}\text { per student } \\
2018^{2}\end{array}$ & $\begin{array}{c}\text { Monthly } \\
\text { income per } \\
\text { student }\end{array}$ & decline & $\begin{array}{c}\text { Monthly } \\
\text { income per } \\
\text { student }\end{array}$ & decline & $\begin{array}{c}\text { Monthly } \\
\text { income per } \\
\text { student }\end{array}$ & decline \\
\hline & & $\mathrm{R} \$(1.00)$ & $\mathrm{R} \$(1.00)$ & $\%$ & $\mathrm{R} \$(1.00)$ & $\%$ & $\mathrm{R} \$(1.00)$ & $\%$ \\
\hline Mean & & 460 & 428 & $-7.0 \%$ & 395 & $-14.1 \%$ & 362 & $-21.3 \%$ \\
\hline Standard de & ation & 136 & 127 & $0.5 \%$ & 118 & $0.9 \%$ & 109 & $1.3 \%$ \\
\hline Coefficient & variation & $29.6 \%$ & $29.6 \%$ & & $29.8 \%$ & & $30.1 \%$ & \\
\hline Lower & & 224 & 209 & $-9.0 \%$ & 194 & $-18.0 \%$ & 179 & $-26.9 \%$ \\
\hline Percentiles & $1 \%$ lower & 288 & 269 & $-8.1 \%$ & 248 & $-16.1 \%$ & 228 & $-24.2 \%$ \\
\hline & 1st quartile & 362 & 337 & $-7.3 \%$ & 311 & $-14.6 \%$ & 285 & $-22.0 \%$ \\
\hline & Median & 435 & 404 & $-7.0 \%$ & 373 & $-14.2 \%$ & 342 & $-21.4 \%$ \\
\hline & 3rd quartile & 518 & 481 & $-6.6 \%$ & 444 & $-13.5 \%$ & 407 & $-20.5 \%$ \\
\hline & $1 \%$ upper & 929 & 865 & $-5.9 \%$ & 801 & $-11.9 \%$ & 738 & $-17.9 \%$ \\
\hline Upper & & 2,451 & 2,314 & $-4.1 \%$ & 2,176 & $-8.3 \%$ & 2,038 & $-12.4 \%$ \\
\hline Range: max & num/minimum & 10.95 & 11.06 & & 11.20 & & 11.37 & \\
\hline Range: $1 \%$ & per/1\% lower & 3.23 & 3.21 & & 3.22 & & 3.24 & \\
\hline
\end{tabular}

\section{Notes:}

(1) Data from the public schools districts of 26 states, the Federal District and 5,531 municipalities were analyzed.

(2) $\mathrm{RPEb} \div$ Number of enrollments $\div 12$.

Source: Elaborated by the authors, based on data from Siope/FNDE, RREO/Siconfi/STN data from the portal 'Constitutional Transfers'/ STN and in microdata from the School Census/Inep (2018). All sources are relative to 2018.

In order to understand the particularities and level of disparity of Brazilian educational contexts, according to the data in Table 4, in 2018 the difference between the lowest value of monthly income per student ( $\mathrm{R} 244.00$ in the city of Monte Horebe-PB $\left.{ }^{4}\right)$ and the highest figure $(\mathrm{R} \$ 2,451.00$ in the city of Douradoquara- $\mathrm{MG}^{5}$ ) was almost 11 times. Even if the extreme values (1\% lower and $1 \%$ upper) are excluded, the difference remains substantial (3.23 times). The data from the scenarios for estimating a drop in revenue in the context of the COVID-19 pandemic reveal that the revenue per student, which is already very low when compared to the tuition of private middle-class schools, could drop significantly: from $4.1 \%$ to $26.9 \%$, depending on the scenario. In scenario I, the drop may vary from $4.1 \%$ to $9.0 \%$. The variation would be from $8.3 \%$ to $18 \%$ in scenario II, and from $12.4 \%$ to $26.9 \%$ in scenario III.

\footnotetext{
${ }^{4}$ Mount Horebe-PB had a population of 4,793 in 2016. In 2018, it provided 1,374 enrolments in the municipal district and was responsible for $82 \%$ of the total basic education enrolment in the municipality.

${ }^{5}$ Douradoquara-MG had about 2,000 inhabitants in 2016 and barely 31 students in the municipal district. It accounted for only $9.7 \%$ of basic education enrollments in the municipality.
} 


\section{CONCLUDING REMARKS}

With the overlapping of the economic and health crises and the interruption of teaching activities for a long-term period, it is reasonable to foresee additional demands for public education which, along with the maintenance of the services already offered, will push the public schools districts to expand their offer in a context of reducing earmarked revenue for education.

How can this challenge be met? Initially, the constitutional role of the Union of supplementing resources is highlighted, taking into account its responsibility to ensure equity and quality standards in education. In this milestone, it is advocated for the immediate increase of the Complementation of the Union to Fundeb. The approval of the Constitutional Amendment Proposal 15/2015 (PEC Proposta de Emenda Constitucional), with the implementation of new Fundeb as early as 2021, is another feasible measure in the short term. The forecast of increasing in the complementation of the Union and new rules for its distribution will benefit municipalities with lower spending capacity in all states of the federation.

The Union's more traditional financial assistance programs for states and municipalities in basic education, which have declined in applications in recent years, require a significant investment of resources. More important, given the scope of coverage, are the National School Meal Programme (Pnae - Programa Nacional de Alimentação Escolar), the National Programme of Support to School Transportation (Pnate - Programa Nacional de Apoio ao Transporte Escolar) and the Direct Money in School Program (PDDE - Programa Dinheiro Direto na Escola).

It is also imperative to implement financial aid from the Union to compensate the loss of earmarked revenue to the maintenance and development of education $(\mathrm{MDE})^{6}$ nationwide, because the complementation to Fundeb, even if it increases in 2020, is for state funds with lower values per student.

Two measures were recently released for compensation of losses in revenues: the Provisional Measure 938/2020 (MP, 2020), which establishes financial support to states and municipalities to sustain the level of resources of the FPE and FPM transferred in the same range of 2019 (with a limit of up to 16 billion reais), between March and June 2020; and Complementary Law 173/2020 (LC, 2020), which creates the Federative Program to confront COVID-19, in which there is a forecast of transfer of 50 billion in the so-called "free resources" (not biding to actions in the areas of health and social assistance) to state governments and municipalities. In both cases, it was not stipulated the compliance of earmarking to MDE.

Although there is a gap in the legal context, it is reasonable to consider administrative and judicial actions to compulsorily allocate part of the mentioned emergency aid to MDE. In any event, in the face of the estimates and measurements of dramatic decreases in tax revenues, measures to protect education income are essential in the short-term. In this regard, Bill No. 3,165, registered in the House of Representatives in early June 2020, advocates the transfer of R $\$ 31$ billion to subnational governments for use in their basic education schools, to be distributed according to the number of in-person enrollments of each entity in 2019. The estimate behind this PL was a $12 \%$ loss in education

\footnotetext{
${ }^{6}$ Art 70 of Law 9,394/1996 (Law of Guidelines and Bases of National Education [LDB - Lei de Diretrizes e Bases da Educação Nacional]) stipulates as expenditure on the maintenance and development of education those that meet the basic objectives of educational institutions.
} 
RAP | Implications of the COVID-19 pandemic on funding basic education

revenues, which is close to the second forecasted scenario (Table 2) in the present study. The amount and distribution criteria will possibly be disputed in the National Congress, themes for which this text provides initial subsidies.

Finally, it is important to emphasize the virtuous role that educational spending plays in the economy (Research Institute for Applied Economics [IPEA - Instituto de Pesquisa Econômica Aplicada], 2011). Between $80 \%$ and $90 \%$ of educational expenditure is allocated to the payment of teachers and school staff (approximately four million workers). Given the remuneration profile of these professionals, a large part of their salaries turns into consumption, with immediate effects on economic activity and tax collection by the 5,570 municipalities where they live. Hence, the educational investment has a huge capillarity, reaching the economic pores of the nation in an organic way. 


\section{REFERENCES}

Alves, T., \& Silva, R. M. (2013). Estratificação das oportunidades educacionais no Brasil: contextos e desafios para a oferta de ensino em condições de qualidade para todos. Educação \& Sociedade, 34(124), 851-879.

Baker, B. D., \& Di Carlo, M. (2020). The coronavirus pandemic and K-12 Education Funding. Washington, DC: Albert Shanker Institute. Retrieved from https:// www.shankerinstitute.org/resource/coronaviruspandemic-and-k-12-education-funding

Bakken, L., Brown, N., \& Downing, B. (2017). Early childhood education: the long-term benefits. Journal of Research in Childhood Education, 31(2), 255-269.

Barros, R. P., Mendonça, R., Santos, D. D., \& Quintaes, G. (2001). Determinantes do desempenho educacional no Brasil (Texto para discusssão n. 834, pp. 1-33). Rio de Janeiro, RJ: IPEA.

Berne R., \& Stiefel. L. (1984). The measurement of equity in school finance: conceptual, methodological and empirical dimensions. London, UK: The John Hopkins University Press.

Buchmann, C., \& Hannum, E. (2001, August). Education and stratification in developing countries: a review of theories and research. Annual Review of Sociology, Palo Alto, 27, 77-102.

Constituição da República Federativa do Brasil, de 5 de outubro de 1988. (1988). Atualizada até a Emenda Constitucional no 106, de 07 de maio de 2020.

Cury, C. R. J. (2008). A educação escolar, a exclusão e seus destinatários. Educação em Revista, (48), 205-222. Retrieved from https://doi.org/10.1590/ S0102-46982008000200010

Instituto de Pesquisa Econômica Aplicada. (2011). Gastos com a Política Social: alavanca para o crescimento com distribuição de renda. (Comunidados do IPEA, n. 75). Brasília, DF: IPEA.

Instituto Nacional de Estudos e Pesquisas Educacionais Anísio Teixeira. (2018). Relatório do segundo ciclo de monitoramento das Metas do Plano Nacional de Educação - 2018. Brasília, DF: Inep.
Lei Complementar n. 173, de 27 de maio de 2020. (2020). Estabelece o Programa Federativo de Enfrentamento ao Coronavírus SARS-CoV-2 (Covid-19), altera a Lei Complementar no 101, de 4 de maio de 2000, e dá outras providências.

Lei n. 9.394, de 20 de dezembro de 1996. (1996). Estabelece as Diretrizes e Bases da Educação nacional, e dá outras providências.

Medida Provisória n. 938, de 02 de abril de 2020. (2020). Dispõe sobre a prestação de apoio financeiro pela União aos entes federativos que recebem recursos do Fundo de Participação dos Estados FPE e do Fundo de Participação dos Municípios - FPM [...].

Organização para a Cooperação e Desenvolvimento Econômico (2019). Education at a Glance 2019. Paris, FR: OECD Publishing. Retrieved from https:// doi.org/10.1787/f8d7880d-en

Phillips, D. A, Lipsey, M. W., Dodge, K. A, Haskins, R., Bassok, D. ...Weiland, C. (2017). Puzzling it out: the current state of scientific knowledge on pre-k effects: a consensus statement. Washington, DC: The Brookings Institution.

Pinto, J. M. R. (2018). O financiamento da educação na Constituição Federal de 1988: 30 anos de mobilização social. Educação \& Sociedade, 39(145), 846-869.

Projeto de Lei n. 3.165, de 08 de junho de 2020. (2020). Dispõe sobre ações emergenciais destinadas à educação básica pública a serem adotadas durante o estado de calamidade pública reconhecido pelo Decreto Legislativo n. 6, de 20 de março de 2020, e dá outras providências.

Watanabe, M. (2020, April 09). Estados já constatam forte queda na receita de ICMS. Valor Econômico. Retrieved from https://valor.globo.com/impresso/ noticia/2020/04/09/estados-ja-constatam-fortequeda-na-receita-de-icms.ghtml

World Bank. (2020, April). The Economy in the Time of Covid-19. LAC Semiannual Report. Washington, DC: World Bank. Retrieved from https://openknowledge.worldbank.org/ handle/10986/33555 License: CC BY 3.0 IGO 


\section{Thiago Alves}

https://orcid.org/0000-0002-5746-3386

Ph.D. in Administration (FEA/USP); Professor at FACE/UFG in the Education (PPGE/UFPR) and Administration (PPGADM/UFG) Graduate Programs. E-mail: thiagoalves.edu@gmail.com

\section{Nalú Farenzena}

https://orcid.org/0000-0003-2582-5925

Ph.D. in Education; Professor at Federal University of Rio Grande do Sul in the Education Graduate Program (FACED/UFRGS); President of the Brazilian Association for Education Funding Research (FINEDUCA). E-mail: nalu.farenzena@gmail.com

\section{Adriana Aparecida Dragone Silveira}

https://orcid.org/0000-0001-6022-627X

Ph.D. in Education; Professor at Federal University of Paraná (UFPR) in the School Planning and Management Department and Graduate Program in Education. E-mail: adrianadragonesilveira@gmail.com

\section{José Marcelino de Rezende Pinto}

https://orcid.org/0000-0001-8355-2561

Ph.D. in Education from UNICAMP; Professor at University of São Paulo; Former president of the Brazilian Association for Education Funding Research (FINEDUCA). E-mail: jmrpinto@ffclrp.usp.br 